\title{
A Sensitive Electrochemical Impedance DNA Biosensor Based on ZnO Nanorod Electrodes for BCR/ABL Fusion Gene Detection
}

\author{
Jiao-yun Xia*, Jing Qing, Jun-jie Liu \\ College of Chemistry and Biological Engineering, Changsha University of Science and Technology, 960, \\ 2nd Section, Wanjiali South RD, Changsha 410114, P. R. China \\ *E-mail: xiajy625@163.com, xiajiaoyun@foxmail.com
}

doi: $10.20964 / 2019.05 .59$

Received: 10 January 2019 / Accepted: 6 March 2019 / Published: 10 April 2019

\begin{abstract}
A ZnO based DNA biosensor was developed to detect complementary target single-stranded DNA (ssDNA) of BCR/ABL fusion gene. $\mathrm{ZnO}$ nanorods (NRs) have been synthesized onto platinized silicon (Pt/Si) substrate using facile and economical chemical bath deposition method. The ssDNA probe was immobilized by electrostatic attraction on the $\mathrm{ZnO} / \mathrm{Pt} / \mathrm{Si}$ surface. The morphology of the samples were characterized by scanning electron microscopy. Electrochemical impedance spectroscopy and cyclic voltammetry were done to study ZnO NR arrays, and the immobilization and the hybridization of ssDNA at the electrode surface. The fabricated DNA biosensor was evaluated in the complementary target ssDNA of BCR/ABL probe in the dynamic range from $1.0 \mathrm{pM} / \mathrm{L}$ to $1.0 \mathrm{nM} / \mathrm{L}$ which indicates a good linearity, high sensitivity and low detection limit of $2.75 \times 10^{-13} \mathrm{~mol} / \mathrm{L}$. The successful detection of BCR/ABL fusion gene exhibits its potential to be a robust and sensitive label-free electrochemical impedance measurement for sensing applications.
\end{abstract}

Keywords: Electrochemical impedance DNA biosensor; BCR/ABL fusion gene; Cyclic voltammetry; Electrochemical impedance spectroscopy

\section{$\underline{\text { FULL TEXT }}$}

(C) 2019 The Authors. Published by ESG (www.electrochemsci.org). This article is an open access article distributed under the terms and conditions of the Creative Commons Attribution license (http://creativecommons.org/licenses/by/4.0/). 